\title{
Effect of the Supplement of Humic Origin on the Free Radical Processes and Histological Changes in the Tissues of Rats Affected by Chromium (VI)
}

\author{
Oksana Buchko ${ }^{\text {(iD), Viktoriia Havryliak }}$ 2,* (D) \\ 1 National Reference Control Laboratory of Veterinary Drug Residues in Product of Animal Origin and Food Additives, \\ State Scientific-Research Control Institute of Veterinary Medicinal Products and Feed Additives, Lviv, Ukraine; \\ buchko_oksana@ukr.net (O.B.); \\ 2 Department of Technology of Biologically Active Substances, Pharmacy and Biotechnology, Lviv Polytechnic National \\ University, Lviv, Ukraine; vitahavryliak@gmail.com (V.H.); \\ * Correspondence: vitahavryliak@gmail.com;
}

Scopus Author ID 55889471800

Received: 19.10.2020; Revised: 12.11.2020; Accepted: 13.11.2020; Published: 15.11.2020

\begin{abstract}
The goal of our study was to examine the effect of feed supplement Humilid on the antioxidant defense system, free radical processes, and histomorphological changes in the tissues of rats affected by Chromium (VI). Rats were divided into 4 groups. Animals of groups $\mathrm{D}_{2}$ and $\mathrm{D}_{3}$ received Humilid in a dose of $2 \mathrm{ml}$ per $\mathrm{kg}$ of body weight for 28 days. From the 14th day of the experiment, rats of groups $\mathrm{D}_{1}$ and $\mathrm{D}_{2}$ were injected by $\mathrm{K}_{2} \mathrm{Cr}_{2} \mathrm{O}_{7}$ in a dose of $2 \mathrm{mg}$ Cr per kg of body weight daily for 14 days. Control animals were injected with saline solution for 14 days. Results showed that $\mathrm{Cr}$ (VI) causes oxidative stress in rat tissues, accompanied by an increase in superoxide dismutase activity, lipid peroxidation products, and a decrease in glutathione peroxidase and glutathione reductase activity. Chromium also caused histopathological changes in the liver and kidney of rats. Watering of rats affected by $\mathrm{Cr}$ (VI) with Humilid leads to decreased oxidative processes, activation of the antioxidant defense system, and reduced pathological effects on animal tissues. Our results indicate the positive influence of Humilid on the rat's organism, inhibiting free radical processes and exhibiting antioxidant, hepatoprotective, and adaptive properties.
\end{abstract}

Keywords: humilid; chromium; rats; antioxidant system; free radical processes; histological changes of tissues.

(C) 2020 by the authors. This article is an open-access article distributed under the terms and conditions of the Creative Commons Attribution (CC BY) license (https://creativecommons.org/licenses/by/4.0/).

\section{Introduction}

Taking into account the growth of xenobiotic pollution, it is essential to study their effects on animals and humans. Compounds of heavy metals are one of the most common chemical risk factors for the health and well-being of organisms [1-3]. The most interesting are metals that are widely used in manufacturing, in particular, chromium. $\mathrm{Cr}$ (VI) is characterized by high ecological mobility and can come from anthropogenic and natural sources [4-9].

Chromium $\left(\mathrm{Cr}^{6+}\right)$ is considered a carcinogen due to its powerful oxidative potential and ability to pass through cell membranes [10-12]. Acidic medium with a high content of organic matter contributes to the reduction of $\mathrm{Cr}$ (VI) to non-toxic $\mathrm{Cr}$ (III) [13]. The opposite process is the formation of $\mathrm{Cr}$ (VI) from $\mathrm{Cr}$ (III), especially in the presence of minerals containing oxides of $\mathrm{Mn}(\mathrm{IV})$. In the presence of $\mathrm{H}_{2} \mathrm{O}_{2}$, intermediate forms of chromium can catalyze Fenton-type reactions by generating highly reactive $\mathrm{OH}^{\bullet}$ radicals $[14,15]$. Toxic $\mathrm{Cr}$ can cause 
body hematological, histological, and morphological changes, growth inhibition, production of reactive oxygen species (ROS), and impaired immune function [16]. It is well known that increasing ROS formation in cells under certain conditions can lead to oxidative stress, which underlies many diseases $[17,18]$.

Considering the potential threat of reactive oxygen metabolites due to heavy metals exposure, the search for biologically active compounds $[19,20]$, which would enhance the functioning of defense systems in organisms against excess ROS, is a very important task. These compounds can include low molecular weight non-enzymatic antioxidants and enzymesantioxidants.

Studies show that humic acids, which form the basis of peat extracts, are absorbed in vivo and can act as active modifying agents of biochemical reactions. They stimulate the recovery of energy levels enhanced by oxygen uptake, resulting in the formation of energyrich molecules necessary for metabolic processes [21]. Due to humic acids' ability to form bonds with metal ions, they are responsible for the formation of complexes with amino acids, peptides, carbohydrates, and steroids.

These humates' physicochemical properties can influence the binding of heavy metals, dismutagenic effect, antioxidant and anticoagulant activity in the tissues [22]. The ability of humic acids to act as ligand-former may explain their involvement in the transport of inorganic ions across biological membranes. Due to the structure's characteristics (high molecular weight and a large number of functional groups), humic substances can form chelates and exhibit an antioxidant effect, reducing the number of oxidized products in the cell [23].

The literature data indicate the preventive effect of humic acids in animals' diet and of wheat affected by lead and cadmium [24-26]. However, there is no data about the effect of humates on metabolic processes and the histostructure of tissues in rats exposed to chromium (VI).

The aim of the study was to determine the effect of the biologically active feed supplement "Humilid" on the antioxidant defense system (ADS), the free radical processes, and histological changes in the tissues of rats affected by $\mathrm{Cr}$ (VI).

\section{Materials and Methods}

\subsection{Experimental animals.}

The experiments were performed on Wistar white male rats with a bodyweight of 170$190 \mathrm{~g}$. The animals were housed in the vivarium's standard condition with free access to drinking water and standard feed for laboratory rats. This study was conducted following the ethical principles of the European Convention for the protection of vertebrate animals used for experimental and other scientific purposes (Strasbourg, 2005), Law of Ukraine "On Protection of Animals from Cruel Treatment" (2006) [27-28].

\subsection{Experimental design.}

The randomized rats were divided into four groups: control (C) and 3 experimental ( $\mathrm{D}_{1}$, $\left.D_{2}, D_{3}\right), 7$ animals in each group. Animals of experimental groups $\mathrm{D}_{2}$ and $\mathrm{D}_{3}$ received a $1 \%$ solution of biologically active feed supplement "Humilid" (TU U 15.7-00493675-004: 2009) in the dose of $2 \mathrm{ml}$ per kg of body weight for 28 days (orally). Rats of groups $\mathrm{D}_{1}$ and $\mathrm{D}_{2}$, starting from the 14th day of the experiment, were intraperitoneally injected with potassium dichromate $\left(\mathrm{K}_{2} \mathrm{Cr}_{2} \mathrm{O}_{7}\right)$ in the dose of $2 \mathrm{mg} \mathrm{Cr}(\mathrm{VI})$ per $\mathrm{kg}$ of body weight daily for 14 days. Animals of 
group $\mathrm{C}$ from 14 days of the experiment were daily injected with $0.9 \% \mathrm{NaCl}$ solution. On day 29, animals of all groups were sacrificed under light ether anesthesia. Homogenates of rat liver, spleen, lungs, and kidney were studied. Tissues were homogenized in $50 \mathrm{mM}$ Tris-HCL buffer (pH 7.4). The ratio of tissues and medium was 1:10 (weight: volume).

\subsection{Histopathological examination.}

Fragments of liver and kidney (0.1-0.3 cm thick) were taken immediately after slaughter and fixed in $10 \%$ neutral buffered formalin for $72 \mathrm{~h}$ at least, washed, dehydrated, and embedded in paraffin, according to the methods [29]. Sections of $7 \mu \mathrm{m}$ thickness were prepared using a rotational microtome NM-340 E and stained with Hematoxylin and Eosin. Examination of histological specimens was performed using a light microscope NIKON ECLIPSE CI-L (Japan) with a microscope-mounted video camera.

\subsection{Biochemical analysis.}

In the tissue homogenates, the activity of superoxide dismutase (SOD, EC 1.15.1.1) was evaluated by the level of inhibition of the rate of NBT-reduction in the presence of NADH and phenazine methosulfate. Catalase (CAT, EC 1.11.1.6) activity was measured by monitoring the formation of a stable colored complex of hydrogen peroxide and molybdenum salts. Glutathione peroxidase (GP, EC 1.11.1.9) activity was determined by the rate of glutathione oxidation in the presence of tert-butyl hydroperoxide and glutathione reductase (GR, EC 1.6.4.2) - by the rate of glutathione recovery in the presence of NADPH. Reduced glutathione (GSH) was quantified by the interaction of SH-groups of glutathione with 5, '5'dithio-bis(2-nitrobenzoic acid). The concentration of lipid hydroperoxides (LHP) was determined by reaction with ammonium thiocyanate. TBA-active products were measured by the reaction between malonic dialdehyde and thiobarbituric acid. Carbonyl groups of proteins (CP) were evaluated by the interaction of carbonyl groups of amino acids with 2,4dinitrophenylhydrazine (Vlizlo, 2012). The absorbance values were measured on a spectrophotometer "Unico" 1205 (USA) [29].

\subsection{Statistical analysis.}

The result among the groups was analyzed by one-way ANOVA, followed by Tukey's multiple comparison tests. Statistical difference was considered significant at $p<0.05$. Results were expressed as mean \pm Standard error of the mean.

\section{Results and Discussion}

\subsection{Indexes of the antioxidant system.}

Our study showed the changes in the antioxidant defense system's indexes, which were similar despite the features of different tissue and metabolic specificity of the organs. Thus, the enzyme SOD activity increased in all tissues of rats affected by Chromium (VI): in the liver and kidney - on 1.2 times, and in the spleen - on 2.5 times, compared with control. In the spleen and kidney of rats of the $\mathrm{D}_{2}$ group, this enzyme activity was also higher than control by 2.21 and 1.3 times, respectively. The activity of CAT was similar in all tissues of rats exposed to $\mathrm{Cr}$ (VI). Only in the lungs, this activity decreased by 1.3 times. Thus, Humilid positively influenced CAT activity by increasing after the administration of $\mathrm{Cr}$ (VI) in comparison with 
control and $\mathrm{D}_{1}$ group in the liver by 1.4 times, in the kidney - by 1.3 times, and in the lungs by 1.2 times (Table. 1). In the tissues of rats treated only with Humilid, SOD and CAT activity were at the level of control.

Table 1. Activity of antioxidant enzymes in rat tissues $(M \pm S E, n=7)$.

\begin{tabular}{|c|c|c|c|c|}
\hline \multirow{2}{*}{ Index } & \multicolumn{4}{|c|}{ Groups of animals } \\
\hline & $\mathbf{C}$ & $\mathbf{D}_{1}$ & $\mathbf{D}_{2}$ & $\mathbf{D}_{3}$ \\
\hline \multicolumn{5}{|c|}{ Liver } \\
\hline SOD (cu/mg prot.) & $22.61 \pm 0.58$ & $27.45 \pm 0.27^{*}$ & $26.06 \pm 0.42$ & $25.37 \pm 0.19$ \\
\hline $\begin{array}{l}\text { CAT } \\
(\mathrm{mmol} / \mathrm{min} \times \mathrm{mg} \text { prot.) }\end{array}$ & $7.70 \pm 0.18$ & $7.71 \pm 0.86$ & $10.46 \pm 0.98^{*}, \#$ & $7.68 \pm 0.19$ \\
\hline \multicolumn{5}{|c|}{ Kidney } \\
\hline SOD (cu/mg prot.) & $21.68 \pm 1.44$ & $26.95 \pm 1.35^{*}$ & $27.93 \pm 1.28^{*}$ & $23.17 \pm 2.20$ \\
\hline $\begin{array}{l}\text { CAT } \\
(\mathrm{mmol} / \mathrm{min} \times \mathrm{mg} \text { prot.) }\end{array}$ & $14.17 \pm 0.62$ & $13.97 \pm 0.38$ & $18.60 \pm 0.89^{* * * *}$,\#\# & $15.36 \pm 0.65$ \\
\hline \multicolumn{5}{|c|}{ Spleen } \\
\hline SOD (cu/mg prot.) & $5.33 \pm 0.16$ & $13.22 \pm 0.59^{*}$ & $11.80 \pm 1.19^{*}$ & $9.47 \pm 0.26$ \\
\hline $\begin{array}{l}\text { CAT } \\
(\mathrm{mmol} / \mathrm{min} \times \mathrm{mg} \text { prot.) }\end{array}$ & $11.39 \pm 0.12$ & $10.45 \pm 0.42$ & $9.91 \pm 0.35$ & $10.18 \pm 0.37$ \\
\hline \multicolumn{5}{|c|}{ Lungs } \\
\hline SOD (cu/mg prot.) & $16.06 \pm 0.52$ & $18.57 \pm 1.24$ & $17.42 \pm 1.46$ & $16.54 \pm 0.89$ \\
\hline $\begin{array}{l}\text { CAT } \\
(\mathrm{mmol} / \mathrm{min} \times \mathrm{mg} \text { prot.) }\end{array}$ & $13.64 \pm 0.55$ & $10.81 \pm 0.34^{* * *}$ & $12.81 \pm 0.52^{\# \#}$ & $14.26 \pm 0.33^{\# \#}$ \\
\hline
\end{tabular}

Note. In this and the next tables: ${ }^{*}$ - the differences are significant between control and experimental rats $\left({ }^{*}-\mathrm{P}\right.$ $\left.<0.05 ;{ }^{* *}-\mathrm{P}<0.01 ;{ }^{* * *}-\mathrm{P}<0.001\right)$; ${ }^{\#}-$ the differences are significant between rats of $\mathrm{D}_{1}$ group and other groups (\# - P < 0.05; \# $-\mathrm{P}<0.01$; \#\# $-\mathrm{P}<0.001) ; \mathrm{C}$ - control group; $\mathrm{D}_{1}$ - rats exposed to $\mathrm{K}_{2} \mathrm{Cr}_{2} \mathrm{O}_{7}$ in the dose of $2 \mathrm{mg}$ $\mathrm{Cr}(\mathrm{VI}) / \mathrm{kg}$ of body weight daily during 14 days; $\mathrm{D}_{2}$ - rats which received food supplement Humilid for 28 days and exposed to $\mathrm{K}_{2} \mathrm{Cr}_{2} \mathrm{O}_{7}$ in the dose of $2 \mathrm{mg} \mathrm{Cr}(\mathrm{VI}) / \mathrm{kg}$ of body weight daily from $14^{\text {th }}$ day of the experiment; $\mathrm{D}_{3}$ - rats which received food supplement Humilid for 28 days in a dose $2 \mathrm{Ml} / \mathrm{kg}$ of body weight.

Biologically active substances of Humilid significantly influence the glutathione chain of the antioxidant defense system in rats' tissues. The activity of the key enzyme of this system - GP, under the influence of Cr (VI) decreased sharply compared with control in all tissues: in the liver - on 1.6 times, in the kidney - on 1.1 times, in the spleen - on 1.5 times, and in lungs - on 1.3 times. Watering rats with Humilid after Chromium administration ( $\mathrm{D}_{2}$ group) caused the increase in this enzyme activity compared with animals affected by Chromium ( $\mathrm{D}_{1}$ group) in the liver and kidney - on 1.5 times, in the lungs - on 1.4 times and kidney - on 1.4 times. In the kidneys of $\mathrm{D}_{2}$ rats, GP's activity also increased by 1.4 times compared to control (Table 2).

Table 2. Indexes of the glutathione chain of the ADS in rat tissues $(M \pm S E, n=7)$.

\begin{tabular}{|c|c|c|c|c|}
\hline \multirow{2}{*}{ Index } & \multicolumn{4}{|c|}{ Groups of animals } \\
\hline & C & $\mathbf{D}_{1}$ & $\mathbf{D}_{2}$ & $\mathbf{D}_{3}$ \\
\hline \multicolumn{5}{|c|}{ Liver } \\
\hline $\begin{array}{l}\text { GP } \\
\text { (nmol GSH/min×mg prot.) }\end{array}$ & $29.06 \pm 1.61$ & $18.26 \pm 1.26^{*}$ & $28.26 \pm 2.58^{\#}$ & $20.10 \pm 0.56$ \\
\hline $\begin{array}{l}\text { GR } \\
(\mu \mathrm{mol} N A D P H / \min \times \operatorname{mg} \text { prot. })\end{array}$ & $2.01 \pm 0.29$ & $0.51 \pm 0.08^{*}$ & $1.48 \pm 0.04^{\#}$ & $1.32 \pm 0.03$ \\
\hline $\mathrm{GSH}(\mathrm{mmol} / \mathrm{g})$ & $0.19 \pm 0.04$ & $0.2 \pm 0.08$ & $0.79 \pm 0.04^{*}, \#$ & $0.26 \pm 0.05$ \\
\hline \multicolumn{5}{|c|}{ Kidney } \\
\hline $\begin{array}{l}\text { GP } \\
\text { (nmol GSH/min×mg prot.) }\end{array}$ & $78.34 \pm 1.08$ & $71.75 \pm 1.11 * *$ & $107.85 \pm 3.42 *$, \# & $90.53 \pm 1.22^{\# \#}$ \\
\hline $\begin{array}{l}\text { GR } \\
(\mu \mathrm{mol} N A D P H / \min \times \operatorname{mg} \text { prot. })\end{array}$ & $2.17 \pm 0.32$ & $2.31 \pm 0.21$ & $3.25 \pm 0.43^{*}$ & $1.92 \pm 0.39$ \\
\hline $\mathrm{GSH}(\mathrm{mmol} / \mathrm{g})$ & $0.28 \pm 0.04$ & $0.28 \pm 0.08$ & $0.47 \pm 0.01^{*}, \#$ & $0.20 \pm 0.03$ \\
\hline \multicolumn{5}{|c|}{ Spleen } \\
\hline $\begin{array}{l}\text { GP } \\
\text { (nmol GSH/min×mg prot.) }\end{array}$ & $37.39 \pm 4.57$ & $24.39 \pm 1.74^{* * *}$ & $22.42 \pm 1.79^{* *}$ & $31.36 \pm 3.12$ \\
\hline $\begin{array}{l}\text { GR } \\
(\mu \mathrm{mol} N A D P H / \min \times \operatorname{mg} \text { prot. })\end{array}$ & $5.02 \pm 0.27$ & $3.96 \pm 0.15^{*}$ & $4.41 \pm 0.34$ & $5.55 \pm 0.12^{\#}$ \\
\hline $\mathrm{GSH}(\mathrm{mmol} / \mathrm{g})$ & $0.14 \pm 0.008$ & $0.15 \pm 0.006$ & $0.17 \pm 0.009^{* *}$ & $0.11 \pm 0.008^{\#}$ \\
\hline
\end{tabular}




\begin{tabular}{l|c|c|c|c}
\multirow{2}{*}{ Index } & \multicolumn{4}{|c}{ Groups of animals } \\
\cline { 2 - 5 } & $\mathbf{C}$ & $\mathbf{D}_{\mathbf{1}}$ & $\mathbf{D}_{\mathbf{2}}$ & $\mathbf{D}_{\mathbf{3}}$ \\
\hline $\begin{array}{l}\text { GP } \\
\text { (nmol GSH/min } \times \text { mg prot.) }\end{array}$ & $42.32 \pm 2.59$ & $32.01 \pm 1.79^{*}$ & $46.16 \pm 2.68^{\#}$ & $50.29 \pm 3.21^{\#}$ \\
\hline $\begin{array}{l}\text { GR } \\
(\mu \mathrm{mol} \mathrm{NADPH} / \mathrm{min} \times \mathrm{mg} \text { prot.) }\end{array}$ & $2.78 \pm 0.56$ & $2.84 \pm 0.34$ & $3.79 \pm 0.66$ & $4.43 \pm 0.15$ \\
\hline GSH (mmol/g) & $0.03 \pm 0.004$ & $0.06 \pm 0.005^{*}$ & $0.07 \pm 0.003^{*}$ & $0.03 \pm 0.004^{\#}$
\end{tabular}

GP's activity in the spleen was less by 1.7 times in the rats that administered humic supplements and chromium. As you can see from table 2 only Humilid didn't influence this enzyme activity in all tissues of rats. This activity was higher in the lungs and kidney than animals of $\mathrm{D}_{1}$ group by 1.6 times and 1.3 times, respectively. The activity of GR in the liver of rats affected by $\mathrm{Cr}$ (VI) decreased 3.9 times and in the spleen - on 1.3 times compared with the control group. At the same time, the combined introduction of Chromium and Humilid is accompanied by the increase in GR activity on 2.9 times compared with $\mathrm{D}_{1}$ group in the spleen and the kidney - on 1.5 times compared with control. The activity of GR in the tissues of rats treated with humic supplement was at the level of control animals, while in the spleen increased on 1.4 times compared with animals exposed to $\mathrm{Cr}$ (VI) (Table 2).

Our results have shown that potassium dichromate administration did not affect the concentration of reduced glutathione in all studied tissues of rats except the lungs, where the twofold increase of reduced glutathione was observed in comparison with control. The combined action of $\mathrm{Cr}$ (VI) and Humilid caused the elevation of this parameter in the liver on 3.5 times, kidney - on 1.5 times, spleen - on 1.2 times compared both control and $\mathrm{D}_{1}$ group, meanwhile in lungs - on 2.3 times compared with the control group. In all studied tissues of rats administered with a humic supplement, the concentration of GSH was at the control level (Table 2).

\subsection{Indexes of free radical processes.}

Our results have shown that intraperitoneal injection of rats by potassium dichromate caused a decrease in lipid hydroperoxides in all studied tissues. Their concentration was lower on 1.5 and 2.7 times in the spleen and lungs. Watering with Humilid the rats exposed by $\mathrm{Cr}$ (VI) leads to an increasing concentration of lipid hydroperoxides in all tissues to control levels. Their content was lower in the kidney and liver of $\mathrm{D}_{2}$ and $\mathrm{D}_{3}$ groups compared with control and $\mathrm{D}_{1}$ rats (Table 3).

Table 3. The content of oxidative stress indexes in rat tissues $(M \pm S E, n=7)$.

\begin{tabular}{|c|c|c|c|c|}
\hline \multirow{2}{*}{ Index } & \multicolumn{4}{|c|}{ Groups of animals } \\
\hline & $\mathbf{C}$ & $\mathbf{D}_{1}$ & $\mathbf{D}_{2}$ & $\mathbf{D}_{3}$ \\
\hline \multicolumn{5}{|c|}{ Liver } \\
\hline LHP (OE/mg) & $0.74 \pm 0.07$ & $0.69 \pm 0.08$ & $0.61 \pm 0.03$ & $0.56 \pm 0.04^{*}$,\# \\
\hline $\begin{array}{l}\text { TBA-active products } \\
(\mathrm{nmol} / \mathrm{mg})\end{array}$ & $3.73 \pm 0.09$ & $4.49 \pm 0.08^{*}$ & $4.55 \pm 0.04^{*}$ & $4.09 \pm 0.08$ \\
\hline $\mathrm{CP}(\mathrm{nmol} / \mathrm{mg}$ prot.) & $0.29 \pm 0.03$ & $1.44 \pm 0.01^{*}$ & $1.02 \pm 0.01^{*}$ & $0.83 \pm 0.09$ \\
\hline \multicolumn{5}{|c|}{ Kidney } \\
\hline LHP (OE/mg) & $0.45 \pm 0.05$ & $0.35 \pm 0.03$ & $0.24 \pm 0.06^{*}$ & $0.19 \pm 0.01^{*}, \#$ \\
\hline $\begin{array}{l}\text { TBA-active products } \\
(\mathrm{nmol} / \mathrm{mg})\end{array}$ & $4.60 \pm 0.31$ & $4.67 \pm 0.47$ & $3.70 \pm 0,27$ & $3.23 \pm 0.28^{*}$, \# \\
\hline $\mathrm{CP}$ (nmol/mg prot.) & $1.24 \pm 0.32$ & $1.52 \pm 0.41$ & $0.68 \pm 0.12^{\#}$ & $0.96 \pm 0.04$ \\
\hline \multicolumn{5}{|c|}{ Spleen } \\
\hline LHP (OE/mg) & $0.68 \pm 0.05$ & $0.45 \pm 0.03^{*}$ & $0.65 \pm 0.02$ & $0.65 \pm 0.05^{\#}$ \\
\hline $\begin{array}{l}\text { TBA-active products } \\
(\mathrm{nmol} / \mathrm{mg})\end{array}$ & $3.86 \pm 0.18$ & $5.51 \pm 0.36^{* *}$ & $5.52 \pm 0.34^{* *}$ & $4.23 \pm 0.31^{\#}$ \\
\hline $\mathrm{CP}$ (nmol/mg prot.) & $1.06 \pm 0.09$ & $2.13 \pm 0.15^{*}$ & $1.25 \pm 0.09$ & $1.36 \pm 0.07$ \\
\hline
\end{tabular}




\begin{tabular}{l|c|c|c|c}
\multirow{2}{*}{ Index } & \multicolumn{4}{|c}{ Groups of animals } \\
\cline { 2 - 5 } & $\mathbf{C}$ & $\mathbf{D}_{\mathbf{1}}$ & $\mathbf{D}_{\mathbf{2}}$ & $\mathbf{D}_{\mathbf{3}}$ \\
\hline LHP (OE/mg) & $0.56 \pm 0,02$ & $0.21 \pm 0.05^{* * *}$ & $0.45 \pm 0.05^{\# \# \#}$ & $0.44 \pm 0.04^{\# \# \#}$ \\
\hline $\begin{array}{l}\text { TBA-active products } \\
\text { (nmol/mg) }\end{array}$ & $2.08 \pm 0.06$ & $2.40 \pm 0.16$ & $2.15 \pm 0.12$ & $1.82 \pm 0.10^{\# \#}$ \\
\hline CP (nmol/mg prot.) & $0.41 \pm 0.09$ & $0.67 \pm 0.02^{*}$ & $0.45 \pm 0.01^{\#}$ & $0.46 \pm 0.002$
\end{tabular}

The concentration of TBA-active products in the tissues of rats exposed by $\mathrm{Cr}$ (VI) was significantly higher in the liver of $\mathrm{D}_{1}$ and $\mathrm{D}_{2}$ groups on 1.2 times and the spleen - on 1.4 times than the control. Humilid contributed to the decrease in the content of the final products of lipid peroxidation in the kidney 1.4 times, in the spleen and lungs - 1.3 times in the $\mathrm{D}_{3}$ group, exposed to heavy metal (Table 3).

Administration of potassium dichromate is accompanied by the increase in the $\mathrm{CP}$ concentration in the liver of $\mathrm{D}_{1}$ rats on 5 times and $\mathrm{D}_{2}$ group - on 3.5 times, in the spleen - on 2 times, and in the lungs - on 1.6 times. Under humic supplement action, the content of carbonyl groups of proteins reduced in the kidney of the $\mathrm{D}_{2}$ group on 2.2 times and in the lungs -1.5 times. The CP concentration in all studied tissues was at the control level in the animals treated with Humilid (Table 3).

Many studies have shown that the mechanism of cell-induced Cr (VI) cytotoxicity is mediated by oxidative stress, increasing the production of reactive oxygen species (ROS) and the formation of superoxide anion and hydroxyl radical. This effect leads to the increase in the intensity of LPS, disruption of the structure of DNA molecules, oxidative damage to lipids, carbohydrates, and proteins [ 30,31$]$. ROS production occurs during the reduction of $\mathrm{Cr}$ (VI) to $\mathrm{Cr}$ (III) in cells, with the formation of its intermediate forms with a lower degree of oxidation (Cr (V), Cr (IV)). Most Chromium (VI) compounds have genotoxic effects in vitro and in vivo due to their solubility and bioavailability, i.e., their ability to penetrate target cells $[4,12,32]$.

In our experiment, intraperitoneal injection of potassium dichromate in a dose of $2 \mathrm{mg}$ $\mathrm{Cr}$ (VI) per kg of body weight daily for 14 days caused inhibition of the antioxidant system, mainly due to the decrease in the activity of a key enzyme of glutathione chain - glutathione peroxidase in all tissues of rats. GR activity decreased in the liver and spleen, and CAT - in the lungs can be explained by the high formation of superoxide anion radical in these organs.

Many researchers $[16,20]$ indicated that the shift of the balance between reactive oxygen species and antioxidants is a potential determinant for the dysfunction of biomolecules and oxidative stress, which plays an important role in the pathogenesis of diseases caused by $\mathrm{Cr}$ (VI). This hypothesis is confirmed by an increase in the content of TBA-active products and $\mathrm{CP}$ in the liver, spleen, and lungs of rats injected with Chromium (VI).

The decrease in the activity of CAT in the lungs and GP in all studied tissues of rats exposed to potassium dichromate can be explained by the fact that the intake of $\mathrm{Cr}$ (VI) leads to its accumulation in the body and simultaneously reducing the level of important trace elements - Iron and Selenium. These elements, contained in enzymes' active sites, can be oxidized by chromium to form incapable of absorption in the intestine [33].

It is shown that Chromium (VI) compounds can cause an increase in the activity of enzymes and metabolites of the antioxidant system depending on the concentrations and duration of administration $[17,30]$. In our study, there was a sharp increase in GSH levels in the lungs and SOD activity in all tissues. In contrast, the GP activity decreased, and the activities of CAT (liver, kidney, spleen) and GH in the kidney and lungs were stable. Compensatory activation of SOD under the action of $\mathrm{Cr}$ (VI) can explain the decrease in the concentration of lipid hydroperoxides in the tissues of $\mathrm{D}_{1}$ rats. Such effects are considered an 
adaptive response and partial activation of the first line of antioxidant defense system to the ROS formation caused by heavy metal on the body.

Literature data report that Humilid feed supplement obtained by two-stage acid-base hydrolysis of peat is known for its antidiarrheal, analgesic, immune-stimulatory, and antimicrobial properties, its ability to influence feed conversion, growth, and quality of meat in farm animals [34-36]. Humates are used in the prevention and therapeutic measures in veterinary practice for all species of animals due to their unique ability of relative neutrality to normal processes and corrective effect in the dysfunction that occurs in the body. This supplement helps to restore physiological functions in pathological conditions and extreme situations [22].

Our study confirms this characteristic of Humilid. Thus, all indexes of the antioxidant defense system and free radical processes in experimental rats' tissues received only a humic supplement (D3 group) at the control level. However, stimulation of the ADS (the higher activity of antioxidant enzymes and GSH concentration) and inhibition of free radical processes (lower concentration of LP, TBA-active products, and CP) in all studied tissues of rats to the level of control values (sometimes below control) was revealed in animals exposed to $\mathrm{Cr}$ (VI) with the previous intake of Humilid with water ( $\mathrm{D}_{2}$ group). We observed these parameters' normalization in this group compared with rats exposed by Chromium ( $\mathrm{D}_{1}$ group).

The obtained results can be explained in two ways. On the one hand, macromolecules of humic acids, containing phenolic groups, can act as antioxidants. They can be electron donors for free radicals, breaking the chain of free radical reactions and reducing the number of LP products and oxidative modification of proteins. Some authors indicate that the high adsorption capacity of humic substances in the gastrointestinal tract $[34,37]$ can lead to the binding of excess $\mathrm{Cr}$ (VI) and its excretion from the body.

On the other hand, fulvic and humic acids contain micro- and macroelements that influence the availability and absorption of these nutrients from feed and facilitate transportation across biological membranes. Thus, humates promote the concentration of essential elements in organs and tissues $[23,38]$ and positively affect the synthesis and activity of enzymes and metabolites of ADS. In our study, this is an increase in SOD and CAT activities, the active site of which includes Zinc, Copper, Iron, and GP - with Selenium in the active site. The intensification of energy and phosphorylation processes by Humilid can explain the increase in GSH concentration and GR activity that restores GSH from the oxidized form in the presence of NADPH [22].

Our data testified the increase in GSH concentration under the combined administration of potassium dichromate and humic compounds in rats. According to the literature data, the reduction of $\mathrm{Cr}(\mathrm{VI})$ to $\mathrm{Cr}(\mathrm{V})$ in natural conditions occurs with low molecular weight thiols, and $95 \%$ of this process takes place with the participation of glutathione [17,33]. The increase in the concentration of GSH under the action of Humilid indicates the activation of the reduction of $\mathrm{Cr}$ (VI) through the intermediate $\mathrm{Cr}$ (V) and $\mathrm{Cr}$ (IV) to non-toxic $\mathrm{Cr}$ (III) and lowering oxidative damage of macromolecules and prevents the oxidative stress, which was found in the lungs and kidney of $\mathrm{D}_{2}$ rats.

Many studies have shown that humic acids, as a powerful complexing agent, bind heavy metals (lead, copper, mercury, cadmium, cobalt, zinc, etc.), actively involved in the liver's metabolism. Like chelated ligands, humates act as a filter and sorbent. However, in contrast to chelated complexes with minerals, humic compounds with heavy metals have a neutral charge; they are insoluble because their assimilation by organisms is difficult [37, 38]. Humates 
immobilize toxic substances, preventing chemical reactions with its participation, and then toxins are excreted from the body. Sahin et al. [26] reported that humic substances reduce $\mathrm{Pb}$ 's harmful effects on the 'chicken's body, improve the function of the thyroid gland, and mitigate inflammation by forming chelates.

Aldmour et al. [8] and Barnie et al. [9] reported that $\mathrm{Cr}$ (VI) is reduced to $\mathrm{Cr}$ (III) in groundwater as a result of reaction with humic substances in a wide range of $\mathrm{pH}$ values, thereby reducing the transport of $\mathrm{Cr}$ (VI) by groundwater. The authors emphasize humic acids' potential due to the phenolic and hydroxyl groups to diminish and remove toxic $\mathrm{Cr}$ from solution in environmental conditions.

\subsection{Histological changes.}

Many researchers believe that to assess the toxicity of substances, microscopic examination of organs is an important biomarker for morphological changes. Literature data indicate that depending on the way chromium enters the body of humans and animals, the accumulation of free radical reaction's product is observed mainly in the liver, kidney, spleen, lungs, brain (in particular, in the hypothalamus and pituitary gland), gonads [14, 39], as well as in the skin and blood cells [40].

In this regard, the prooxidant effects of Chromium (VI) can mediate dysfunction of various organs and systems and play an important role in the hemotoxic, immunotoxic, hepatotoxic, pulmotoxic, nephrotoxic, gonadotoxic, and carcinogenic effects of this element $[3,5,10,13,19]$.

It is known that the liver is one of the most important organs that protect the body from the harmful effects of various toxins, acting as a universal metabolic barrier. Also, hepatocyte enzyme systems provide complete or partial neutralization of toxins, including heavy metals. Therefore, liver histology is a useful diagnostic tool for general health assessment due to the important role of this organ in various metabolic processes [20, 31].

The liver sections' examination in rats of the control group showed normal histological architecture (Fig.1, C). There are visible hepatocytes (H), central vein, triad (T) (artery, vein, bile duct) on the section. The cytoplasm of hepatocytes is mainly basophilic, uniformly colored; its nuclei are large, round, contain one, rarely two nucleoli, chromatin accumulations are visible on the periphery. In general, no dystrophic lesions or morphological changes were detected in the liver of the control rats.

Dystrophic and inflammatory focal changes were detected in the liver sections of rats of the first experimental group, injected with $\mathrm{Cr}(\mathrm{VI})$. The central vein (V) is visible, filled with cellular elements of blood, which narrow the lumen of sinusoids and disturb the bloodstream. Dystrophic lesions of parenchymal tissue (D) are observed around it. The section shows flattened hepatocytes $(\mathrm{H})$, reduced intensity of their color, and pronounced granularity of the cytoplasm (Fig. 1, D 1 ).

Changes in the liver structure of experimental rats injected with potassium dichromate + Humilid were less pronounced than in animals exposed with only chromium (VI). There is single necrosis of the liver parenchyma $(\mathrm{N})$, but with less intensity than in rats of group $\mathrm{D}_{1}$ (Fig. 1, D 2 ). 

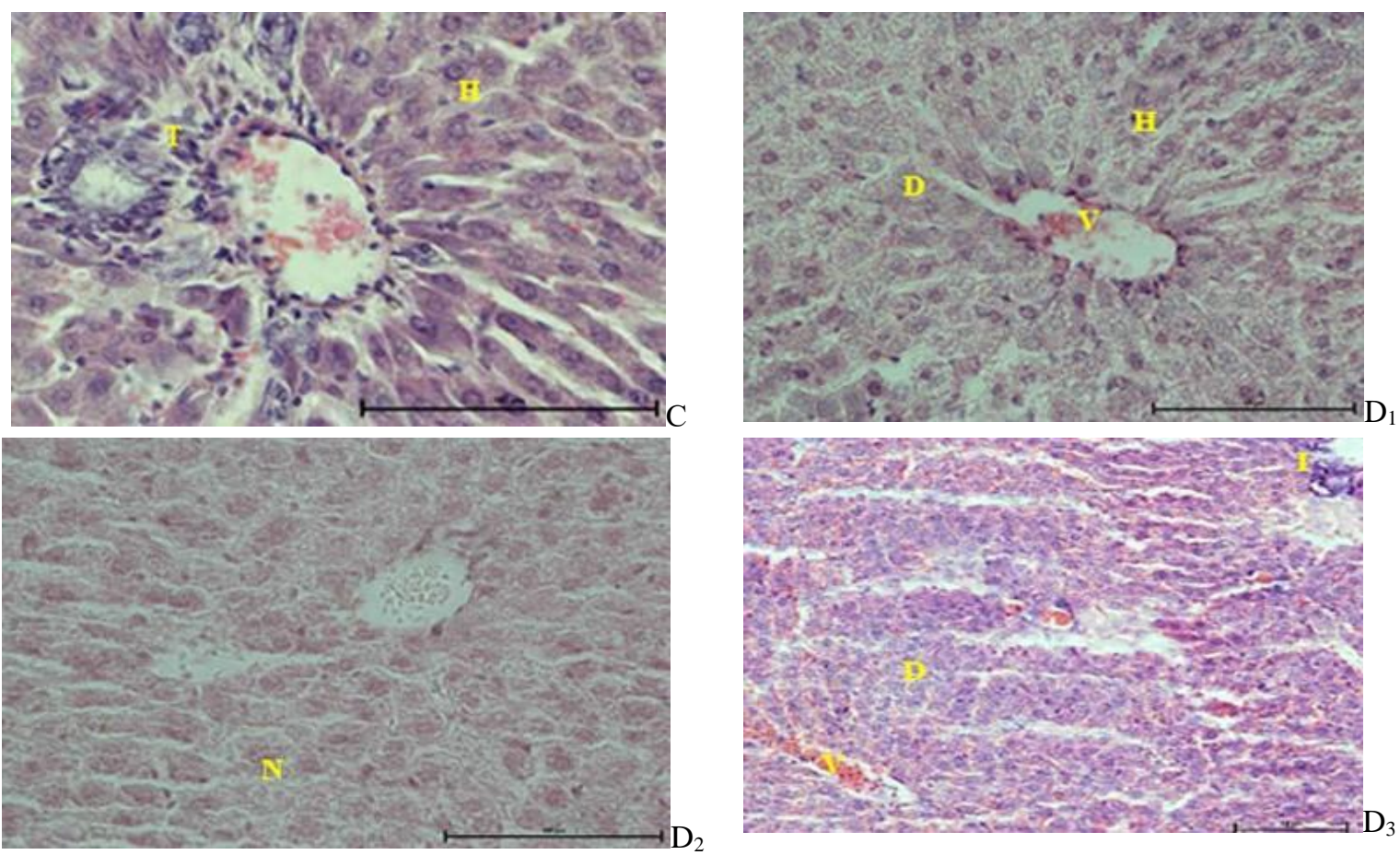

Figure 1. Microstructure of the liver in rats: $\mathrm{C}-$ control; $\mathrm{D}_{1}-\mathrm{Cr}(\mathrm{VI}) ; \mathrm{D}_{2}-$ Humilid $+\mathrm{Cr}(\mathrm{VI})$; $\mathrm{D}_{3}-$ Humilid.

Hematoxylin and eosin, magnification 40x. T - triad; $\mathrm{H}$ - hepatocytes; $\mathrm{V}$ - central vein; $\mathrm{D}$ - dystrophic changes; I - inflammation; $\mathrm{N}$ - necrosis.

In the experimental rats' liver, treated only humic supplement revealed a slight inflammation (I) between the bile duct and vein. The partial parenchymal dystrophy (D) and narrowing of the central vein (V) are observed due to insignificant accumulation of polymorphic cells formed by lymphocytes, neutrophils, monocytes of different degree of maturity (Fig. 1, D 3 ).

Our results are similar to the studies of other authors. Thus, studies [30, 31] showed an increasing number of lipid vacuoles in hepatocytes of fishes exposed to chromium chloride $(2.0 \mathrm{mg} / \mathrm{kg})$ and $\mathrm{K}_{2} \mathrm{Cr}_{2} \mathrm{O}_{7}(20$ and $40 \mathrm{mg} / \mathrm{l})$, which can explain poor regulation of reserves lipids due to toxic effects. The authors observed hepatocyte atrophy, a lateral arrangement of nuclei, and enlargement of the sinusoidal space [41]. Condensed nuclei in chromium-induced hepatocytes (karyomegaly) can be associated with lipid and glycogen precipitation. The authors note that high concentrations of $\mathrm{Cr}$ (VI) cause degeneration of liver tissue and necrosis of the central vein and as a result of the accumulation of neutrophils and lymphocytes [1].

The partial dystrophy and insignificant filling of the central vein with blood cells observed in rats' liver after feeding Humilid requires further study. Thus, Reham et al. studied the histological specimens of the fish liver treated with $0.2 \%$ humic acid and found single samples with a sign of cell degeneration and vacuolation compared to the control [23]. Verigo et al. showed that the use of mineral water with high content $\left(278.2 \mathrm{mg} / \mathrm{dm}^{3}\right)$ of humic acids in rats with experimental hepatitis did not reduce the violation of the hepatocytes ultrastructure, caused by a pathological process [42].

On the other hand, Ryzhkovskaia et al. showed that the consumption of mineral water containing humic acids at a dose of $20 \mathrm{mg} / \mathrm{dm}^{3}$ for 21 days in rats with paracetamol experimental hepatitis caused a modification of the ultrastructure of hepatocytes. An increase in the number of granular endoplasmic reticulum cisterns, glycogen granules, and mitochondrial polymorphism was observed that led to the restoration of energy, glycogen, and 
protein synthesis affected by paracetamol intake. The aftereffect phase was characterized by further enhancement of reparative processes and functional activity of liver cells [43].

The literature data provides evidence of the hormone-like action of humic acid metabolites in the liver of domestic animals [22, 37], the energy supply of hepatocytes due to the activation of electron transport in the respiratory chain mitochondria, and oxidative phosphorylation. The authors noted that the use of humic preparations at a dose of $1 \%$ of the active substance in drinking water for 24 days did not cause intoxication in the liver's mitochondria.

We found a positive effect of humic supplements on rats' body, which was manifested by a weakening of the dystrophic and necrotic effects of hexavalent chromium. Therefore, we believe that humid reduces the harmful effects of heavy metal salts on the liver, stimulating proliferative processes and regeneration.
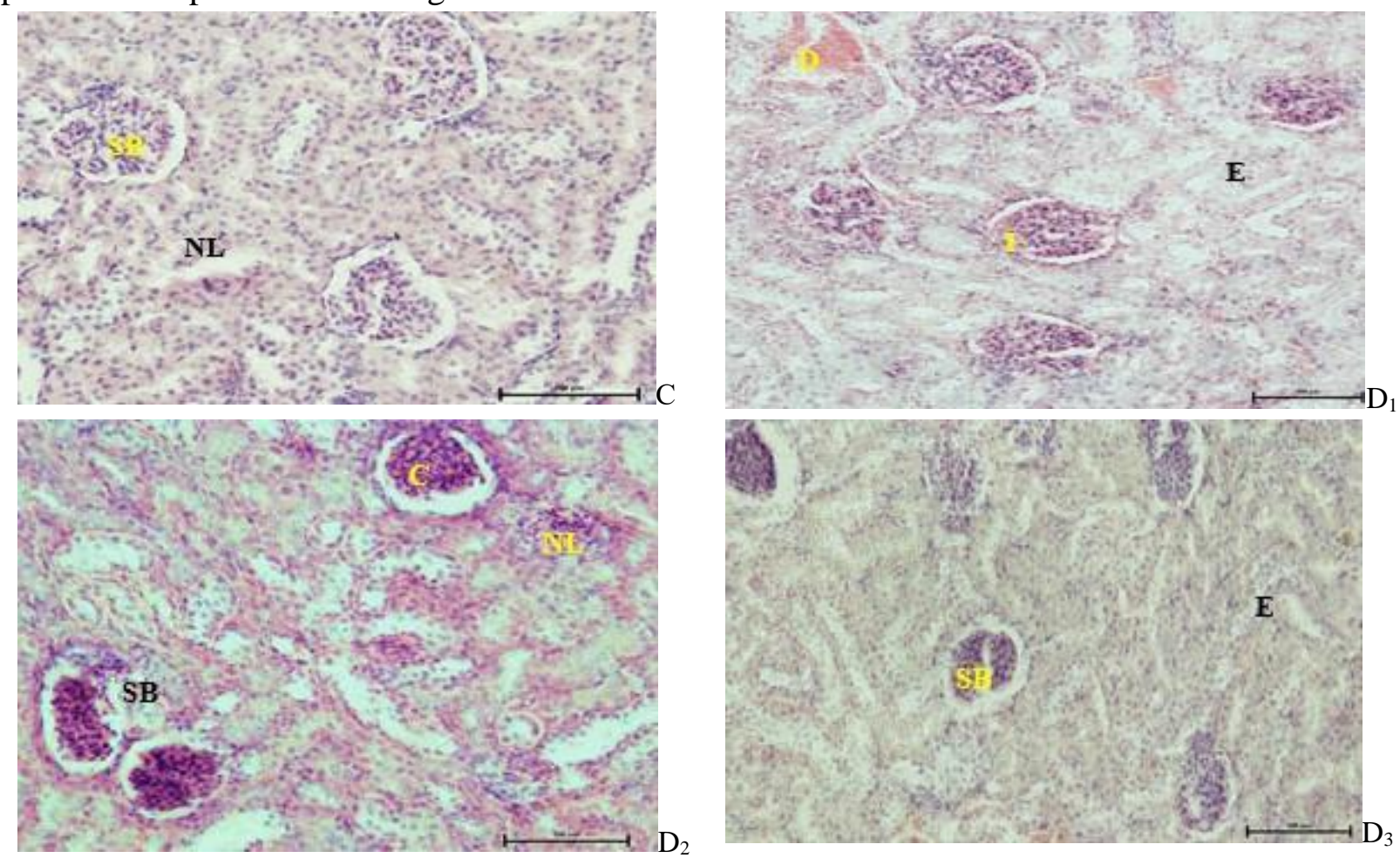

Figure 2. Microstructure of the kidney in rats: $\mathrm{C}-$ control; $\mathrm{D}_{1}-\mathrm{Cr}(\mathrm{VI}) ; \mathrm{D}_{2}-\mathrm{Humilid}+\mathrm{Cr}(\mathrm{VI}) ; \mathrm{D}_{3}-$ Humilid. Hematoxylin and eosin, magnification 20x. NL - loops of the nephron; SB - Shumlyansky- Bowman capsule; C - renal corpuscle; E - epithelial tissue; D - dystrophic damage; I - inflammation.

Literature data $[1,18,44]$ indicate that the kidney is the main "critical" target organ of toxic chromium accumulation. The generation of free radicals caused by this heavy metal leads to the peroxidation of unsaturated fatty acids in cell membranes and renal necrosis development. The authors note that $\mathrm{K}_{2} \mathrm{Cr}_{2} \mathrm{O}_{7}$ in the doses of 10 and $15 \mathrm{mg} / \mathrm{kg}$ of body weight of rats affects the renal tubules, causing hypertrophy of epithelial cells, reduction of tubular lumens, glomeruli reduction, epithelial and glomerular necrosis. Epithelial hypertrophy decreased lumen, and tubular atrophy, necrosis of the glomeruli in fish exposed to $\mathrm{Cr}$ (VI) are shown by Mishra [31].

Our studies showed that the kidney's histostructure in the control rats (Fig. 2, C) is not changed. Visible proximal and distal loops of the nephron (NL), and vascular glomerulus in the Shumlyansky-Bowen capsule were seen in the specimen (SB).

In rats of the first experimental group, injected of $\mathrm{Cr}(\mathrm{VI})$ revealed dystrophic changes and focal inflammation in the kidney tissue. The histosection shows vessels full of blood (D), 
single vascular glomeruli enlarged in volume with signs of inflammation (I), and swollen epithelium. There are dystrophic changes in the epithelial tissue of the nephron's loops (E) (Fig. 2, $\left.\mathrm{D}_{1}\right)$.

The morphostructural changes of the kidney in rats administered by potassium dichromate and Humilid was less pronounced than in animals exposed by only heavy metal. The partial increase in the size of the Shumlyansky capsule (SB) and the renal corpuscle (C) and slight inflammation of the nephron loops (NL) were detected (Fig. 2, $\mathrm{D}_{2}$ ).

Small changes in the kidneys' epithelium were found in rats of the third experimental group received the only humic supplement. It was revealed the swollen epithelium and enlargement of the Shumlyansky-Bowman capsule (SB) due to a slight proliferation of connective tissue (E) (Fig. 2, D3).

\section{Conclusions}

Thus, our studies have shown that Humilid alleviates intoxication of rat tissues, exhibits hepato-, nephroprotective and anti-inflammatory effects, activates protective systems' functioning, stimulates adaptation, and inhibits free radical processes induced by heavy metal in the body. The use of the humic supplement in a dose of $1 \%$ of the active substance in drinking water for 28 days did not cause pathological changes in rats' organs. The obtained results give arguments to recommend the mentioned supplement to further research for implementation in medical practice.

\section{Funding}

This research received no external funding.

\section{Acknowledgments}

The authors express deep gratitude to the specialist of the laboratory of molecular biology and clinical biochemistry of the Institute of Animal Biology of NAAS Martyn Yu. V. for assistance in conducting histological examinations.

\section{Conflicts of Interest}

The authors declare no conflict of interest.

\section{References}

1. Authman, M.M.N.; Zaki, M.S.; Khallaf, E.A.; Abbas, H.H. Use of Fish as Bio-indicator of the Effects of Heavy Metals Pollution. J Aquac Res Development 2015, 6, 1-13, https://doi.org/10.4172/21559546.1000328.

2. Ali, H.; Khan, E.; Ilahi, I. Environmental Chemistry and Ecotoxicology of Hazardous Heavy Metals: Environmental Persistence, Toxicity, and Bioaccumulation. Journal of Chemistry 2019, 1-15, https://doi.org/10.1155/2019/6730305.

3. Fu, Z.; Xi, S. The effects of heavy metals on human metabolism. Toxic. Mechan. Meth. 2020, 30, 167-176, https://doi.org/10.1080/15376516.2019.1701594.

4. Ali, H.; Khan, E. Bioaccumulation of non-essential hazardous heavy metals and metalloids in freshwater fish. Risk to human health. Environ. Chem. Lett. 2018, 16, 903-917, https://doi.org/10.1007/s10311-0180734-7.

5. Tumolo, M.; Ancona, V.; Paola, D.; Losacco, D.; Campanale, C.; Massarelli, C.; Uricchio, V.F. Chromium Pollution in European Water, Sources, Health Risk, and Remediation Strategies: An Overview. Int. J. Environ. Res. Public Health 2020, 17, https://doi.org/10.3390/ijerph17155438. 
6. Zhang, D.; Xu, Y.; Li, X.; Wang, L.; He, X.; Ma, Y.; Zou, D. The Immobilization Effect of Natural Mineral Materials on Cr (VI) Remediation in Water and Soil. Int. J. Environ. Res. Public Health 2020, 17, 28-32; https://doi.org/10.3390/ijerph17082832.

7. Korkmaz, C.; Ay, O.; Ersoysal, Y.; Koroglu, M.A.; Erdem, C. Heavy metal levels in muscle tissues of some fish species caught from north-east Mediterranean: Evaluation of their effects on human health. J. Food Comp. Anal. 2019, 81, 1-9, https://doi.org/10.1016/j.jfca.2019.04.005.

8. Aldmour, S.T.; Burke, I.T.; Bray, A.W.; Baker, D.L.; Ross, A.B.; Gill, F.L.; Cibin, G.; Ries, M.E.; Stewart, D.I. Abiotic reduction of $\mathrm{Cr}(\mathrm{VI})$ by humic acids derived from peat and lignite: kinetics and removal mechanism. Environmental Science and Pollution Research 2019, 26, 4717-4729, https://doi.org/10.1007/s11356-018-3902-1.

9. Barnie, S.; Zhang, J.; Wang, H.; Yin, H.; Chen, H. The influence of $\mathrm{pH}$, co-existing ions, ionic strength, and temperature on the adsorption and reduction of hexavalent chromium by undissolved humic acid. Chemosphere 2018, 212, 209-218, https://doi.org/10.1016/j.chemosphere.2018.08.067.

10. Ray, R.R. Adverse haematological effects of hexavalent chromium: an overview. Interdiscip Toxicol. 2016, 9, 55-65, https://doi.org/10.1515/intox-2016-0007.

11. Deng, Y.; Wang, M.; Tian, T.; Lin, S.; Xu, P.; Zhou, L.; Dai, C.; Hao, Q.; Wu, Y.; Zhai, Z.; Zhu, Y.; Zhuang, G.; Dai, Z. The Effect of Hexavalent Chromium on the Incidence and Mortality of Human Cancers: A MetaAnalysis Based on Published Epidemiological Cohort Studies. Front. Oncol. 2019, 9, https://doi.org/10.3389/fonc.2019.00024.

12. Pal, S.; Shil, K. Metabolic Toxicity and Alteration of Cellular Bioenergetics by Hexavalent Chromium. In: Handbook of Environmental Materials Management. Hussain, C.M., Ed.; 2018; pp. 1-28, https://doi.org/10.1007/978-3-319-58538-3_58-1.

13. Kośla, T.; Lasocka, I.; Kołnierzak, M. Chromium, Cr. In: Mammals and Birds as Bioindicators of Trace Element Contaminations in Terrestrial Environments. Kalisińska, E. Ed.; 2019; pp. 57-124, https://doi.org/10.1007/978-3-030-00121-6_3.

14. Guo, Y.; Wang, Y.; Huang, B. The acute toxicity effects of hexavalent chromium in antioxidant system and gonad development to male clam Geloina coaxans. The European Zoological Journal 2020, 87, 325-335, https://doi.org/10.1080/24750263.2020.1775318.

15. Kotyk, B.; Iskra, R.; Sushko, O.; Slivinska, O.; Klymets, G.; Buchko, O.; Pylypets, A.; Pryimych, V. Effect of ethylthiosulfanylate and chromium (VI) on the pro/antioxidant system in rats blood. The Animal Biology 2019, 21, 38-45, https://doi.org/10.15407/animbiol21.04.038.

16. Iskra, R.; Antonyak, H. Chromium in Health and Longevity. In: Trace Elements and Minerals in Health and Longevity. Healthy Ageing and Longevity. Malavolta, M.; Mocchegiani, E. Ed.; Springer, Cham, 2018; pp. 133-162, https://doi.org/10.1007/978-3-030-03742-0_5.

17. Burmas, N.I. The state of antioxidant system and bile formation function in the organism of rats affected by hexavalent chromium compounds. Med and Clin Chem. 2016, 18, 89-93, https://doi.org/10.11603/mcch.2410-681X.2016.v0.i1.6280.

18. Hegazy, R.; Salama, A.; Mansour, D.; Hassan, A. Renoprotective Effect of Lactoferrin against ChromiumInduced Acute Kidney Injury in Rats: Involvement of IL-18 and IGF-1 Inhibition. PLoS ONE 2016, 11, https://doi.org/10.1371/journal.pone.0151486.

19. Hassan, M.M.; Wesam, A.E.; Rehab, M.M.; Amira, A.M. An Evaluation of Hepatotoxicity, Nephrotoxicity, and Genotoxicity Induced by Acute Toxicity of Hexavalent Chromium and Comparison of the Possible Protective Role of Selenium and Vitamin E on These Effects. Ain Shams J Forensic Med Clin Toxicol. 2019, 33, 48-58, https://doi.org/10.21608/AJFM.2019.36574.

20. Balakrishnan, R.; Satish Kumar, C.S.; Rani, M.U.; Srikanth, M.K.; Boobalan, G.; Reddy, A.G. An evaluation of the protective role of $\alpha$-tocopherol on free radical induced hepatotoxicity and nephrotoxicity due to chromium in rats. Indian J Pharmacol. 2013, 45, 490-495, https://doi.org/10.4103/0253-7613.117778.

21. Calısır, M.; Akpınar, A.; Poyraz, O.; Goze, F.; Cınar, Z. Humic Acid, a Polyphenolic Substance, Decreases Alveolar Bone Loss in Experimental Periodontitis in Rats. Journal of Veterinary Dentistry 2019, 36, $257-$ 265, https://doi.org/10.1177/0898756420910531.

22. Stepchenko, L.M.; Shaidek, L.; Novik, V.; Sotnikova, O.P.; Haluzina, L.I. Achievements and prospects of humic substances application in agriculture. Astra-Prynt: Dnipro, Ukraine 2017, 164.

23. Reham, A.A.; Mounes, H.A.M.; Ahmed, K.M. Use of humic acid and Yucca extract as a benefactor on water quality and their impact on some hematological and histological parameters of Oreochromis niloticus. Egyptian Journal of Aquatic Biology \& Fisheries 2018, 22, 447-460, https://doi.org/10.21608/ejabf.2019.24361.

24. Konakci, O.C.; Yildiztugay, E.; Bahtiyar, M.; Kucukoduk, M. The humic acid-induced changes in the water status, chlorophyll fluorescence and antioxidant defense systems of wheat leaves with cadmium stress. Ecotoxicology and Environmental Safety 2018, 155, 66-75, https://doi.org/10.1016/j.ecoenv.2018.02.071.

25. Akcin, A.; Akcin, T.A. Protective effects of humic acid against chromium stress in wheat (Triticum aestivum L. cv. Delabrad-2). J. Int. Envir. Applic. \& Sci. 2019, 14, 50-58. 
26. Sahin, A.; Iskender, H.; Terim, K.K.A.; Altinkaynak, K.; Hayirli, A.; Gonultas, A.; Kaynar, O. The effect of humic acid substances on the thyroid function and structure in lead poisoning. Braz J of Poultry Sci. 2016, 18, 649-654, https://doi.org/10.1590/1806-9061-2016-0299.

27. Directive 2010/63/EU of the european parliament and of the council of 22 September $\mathbf{2 0 1 0}$ on the protection of animals used for scientific purposes. Official Journal of the European Union L276/33. 86/609/EC. 20.10.2010.

28. Law of Ukraine “"'On Protection of Animals from Cruel Treatment"”Vidomosti Verhovnoi Rady Ukrainy Official Bulletin of the Verkhovna Rada of Ukraine 2006, 21 February, 27.

29. Vlizlo, V.V.; Fedoruk, R.S.; Ratych, I.B. Laboratory methods of investigation in biology, stockbreeding and veterinary. 2rd ed.; Spolom: Lviv, Ukraine, 2012; pp. 762.

30. Ahmed, A.R.; Jha, A.N.; Davies, S.J. The Effect of Dietary Organic Chromium on Specific Growth Rate, Tissue Chromium Concentrations, Enzyme Activities and Histology in Common Carp, Cyprinus carpio L. Biological Trace Element Research 2012, 149, 362-370, https://doi.org/10.1007/s12011-012-9436-3.

31. Mishra, A.K.; Mohanty, B. Acute toxicity impacts of hexavalent chromium on behavior and histopathology of gill, kidney and liver of the freshwater fish, Channa punctatus (Bloch). Environm Toxicol and Pharm. 2008, 26, 136-141, https://doi.org/10.1016/j.etap.2008.02.010.

32. Zhitkovich, A. Chromium in Drinking Water: Sources, Metabolism, and Cancer Risks. Chem. Res. Toxicol. 2011, 24, 1617-1629, https://doi.org/10.1021/tx200251t.

33. Mihaylova, I.V.; Smolyagin, A.I.; Krasikov, S.I.; Karaulov, A.V. Complex assessment of chromium on rats: immunology, biochemistry, trace elements. Immunologiya 2015, 36, 300-305.

34. Visscher, C.; Hankel, J.; Nies, A.; Keller, B.; Galvez, E.; Strowig, T.; Keller, C.; Breves, G. Performance, Fermentation Characteristics and Composition of the Microbiome in the Digest of Piglets Kept on a Feed With Humic Acid-Rich Peat. Front. Vet. Sci. 2019, 6, 1-10, https://doi.org/10.3389/fvets.2019.00029.

35. El-Zaiat, H.; Morsy, A.; El-Wakeel, E.; Anwer, M.; Sallam, S. Impact of humic acid as an organic additive on ruminal fermentation constituents, blood parameters and milk production in goats and their kids growth rate. J. Anim. Feed Sci. 2018, 27, 105-113, https://doi.org/10.22358/jafs/92074/2018.

36. Terry, S.A.; Ribeiro, G.O.; Gruninger, R.J.; Hunerberg, M.; Ping, S. Effect of humic substances on rumen fermentation, nutrient digestibility, methane emissions, and rumenmicrobiota in beef heifers. J. Anim. Sci. 2018b, 96, 3863-3877.

37. Dyomshina, O.O.; Ushakova, G.O.; Stepchenko, L.M. The effect of biologically active feed additives of humilid substances on the antioxidant system in liver mitochondria of gerbils. Regul Mech Biosyst. 2017, 8, 185-190, https://doi.org/10.15421/021729.

38. Szabó, J.; Vucskits, A.V.; Berta, E.; Andrásofszky, E.; Bersényi, A.; Hullár, I. Effect of fulvic and humic acids on iron and manganese homeostasis in rats. Acta Vet Hung. 2017, 65, 66-80, https://doi.org/10.1556/004.2017.007.

39. Jeevana, L.M.; Srikanth, M.K.; Gopala, R.A.; Anudeep, R.M. Haematological study in hexavalent chromium toxicity in female wistar rats and its progeny. The Pharma Innov. J. 2018, 7, 35-38.

40. Karaulova, A.V.; Renieri, E.A.; Smolyaginc, A.I.; Mikhaylovad, I.V.; Stadnikove, A.A.; Begunc, D.N.; Tsarouhas, K.; Djordjevicg, A.B.; Hartungh, T.; Tsatsakis A. Long-term effects of chromium on morphological and immunological parameters of Wistar rats. Food and Chemical Toxicology 2019, 133, 111, https://doi.org/10.1016/j.fct.2019.110748.

41. Velma, V.; Tchounwou, P.B. Chromium-induced biochemical, genotoxic and histopathologic effects in liver and kidney of goldfish, carassius auratus. Mutation Research - Genetic Toxicology and Environmental Mutagenesis 2010, 698, 43-51, https://doi.org/10.1016/j.mrgentox.2010.03.014.

42. Verigo, N.S.; Ryzhkovaskaya, E.L.; Kuznetsova, T.E.; Ulashchik, V.S. Changes in the structural and functional state of the liver in rats with hepatitis drinking weakly mineralized mineral water with elevated content of humic acids. Physiotherapy, balneology and rehabilitation 2013, 5, 4-10.

43. Ryzhkovskaia, E.L.; Verigo, N.S.; Kuznetsova, T.E.; Ulashchik, V.S. The ultrastructural organization of the liver of rats with experimental hepatitis after drinking mineral water containing humic acids. Voprosy Kurortologii, Fizioterapii, i Lechebnoi Fizicheskoi Kultury 2014, 5, 35-41.

44. Shil, K.; Pal, S. Metabolic adaptability in hexavalent chromium-treated renal tissue: an in vivo study. Clinical Kidney Journal 2018, 11, 222-229, https://doi.org/10.1093/ckj/sfx069. 